\title{
新时期技工院校班主任管理工作的创新
}

向辉

云南红河技师学院

DOI:10.32629/er.v2i2.1684

[摘 要] 在目前教育改革工作不断推进背景下,技工院校对班主任管理工作也提出了更为严格的标准和要求, 班主任工作更 需要兼顾多个方面,从而实现对管理方式和手段的优化,提升管理效率。基于技工院校班主任管理问题,本文从新时期技工院校 班主任管理出发,进一步研究对工作的创新,希望对班主任管理工作效率的提升提供指导意见。

[关键词] 新时期; 技工院校; 班主任管理

随着社会的发展及教育改革的稳步推进, 技工院校的教 育管理作为教育领域的重要组成, 也逐渐受到了人们的关注 和重视。而技工院校的班主任在管理过程中, 会受到多重因 素的限制和影响, 对班级管理工作的质量也将产生直接性影 响。因此, 有效进行班主任班级管理的创新, 提升班主任管理 水平是当前需要研究的重要问题。

\section{1 技工院校班主任管理工作存在的主要问题}

通过对当前技工院校班主任管理的研究发现, 这项工作 仍然存在很多问题, 受多种因素的影响较为显著。就学生层 面而言, 由于学生刚到全新的学习和成长环境中, 加之社会 的多元化, 其思维意识和学习理念也将产生明显变化。一些 西方不良思想对技工院校学生的行为产生了严重影响, 甚至 制约了学生价值观的正常发展, 这必然会对班主任的班级管 理带来一定难度 ${ }^{[1]}$ 。并且在全新社会背景下, 学生个性意识 更为突出, 因此难以实现对学习积极性的提升, 如果这一环 节中班主任不能对学生进行科学引导和管理, 学生的发展就 会受到极大影响。就家长层面而言, 家长教育意识的偏差也 会给班主任管理工作带来重要影响。有的家长认为把学生送 到职业院校, 目的就是要让孩子掌握一技之长, 至于对孩子 的教育, 则全权交付给教师。这种意识的存在使得班主任在 管理的过程中, 出现和家长沟通困难的问题, 家长如果不能 和班主任进行及时交流, 对于学生的情况掌握不到位, 将会 对班级管理工作的开展产生严重阻力 ${ }^{[2]}$ 。

\section{2 新时期技工院校学生的主要特征}

第一, 技工院校的学生大多来自于初中毕业生, 并且这 些初中毕业生的基础相对比较薄弱, 缺乏学习自主性和积极 性, 对教师的依赖比较严重。第二, 技工院校的学生正处于青 春期, 在这一年龄阶段中, 学生不仅具备较强的好奇心和求 知欲, 喜欢上网、玩游戏等休闲方式, 还有着思想不稳定的特 点, 容易产生冲动, 学习和生活中经常出现摇摆问题。第三, 技工院校的学生自身基础较差, 在学习中存在较强自卑感, 对学习缺乏热情, 甚至还会出现厌学、逃学的情况, 这些问题 的出现都会对班主任管理工作的顺利开展产生较大限制性 影响 ${ }^{[3]}$ 。

\section{3 技工院校班主任管理工作的创新对策}

为了进一步提升技工院校班主任管理质量和效率, 教师 需要从多个方面对工作进行关注, 提升管理工作科学性, 只 有保证基础工作的有效开展, 才能实现班主任管理工作效率 和质量的双提升。基于上述班主任管理问题，下文将提出相 应创新对策, 以期帮助班主任管理工作实现稳定发展。

3.1 强化对学生实际情况的了解

要想有效推进班级管理工作的顺利开展, 班主任就要对 学生的情况进行全面掌握。只有确保对学生实际情况进行准 确掌握, 才能在实际管理中制定更具针对性的对策, 切实实 现班级管理水平和效率的提升。在此环节中, 班主任要积极 引导学生, 在日常学习和生活中加强与学生之间的平等交流, 让学生感受到班主任的亲切关怀。此外, 班主任还要加强日 常生活中和家长的交流, 更准确的掌握学生生活情况, 这对 于班主任的针对性管理也将提供有效指导和帮助 ${ }^{[4]}$ 。

3.2 优化班级管理工作

班主任在班级管理的过程中, 应该进一步强化管理工作 的质量, 从而提升整个班级的团队意识; 强化学生的整体意 识, 实现管理效率和水平的全面提升; 教师还要根据班级实 际情况制定相关的规章制度, 在落实制度实施环节中, 实现 对班级管理水平的全面提升。

3.3 加强对班级干部的有效培养

班级需要有自己的领头人和组织者, 以实现自我管理、自 我约束和自我提高。所以班主任在引导班级积极健康发展的过 程中应刻意培养一些领头羊一一班干部, 使他们真正成为班主 任的得力助手, 成为全班同学的表率和楷模。平时要引导班干 部科学的安排时间, 正确处理好班级工作与学习的关系, 引领 他们有胆量, 肯干、能干, 培养他们具有高尚的道德品质、文明 的行为规范、积极向上的精神面貌和强烈的工作责任感, 带动 全班学生内在自我教育的主动性和奋发向上的积极性, 真正做 到自我教育, 不断提高思想道德素质水平。

3.4 班主任工作要保证决心、责任心和恒心的结合

首先, 班主任在工作中要具备干好班主任工作的决心。 在班主任工作中, 需要有和学生共同成长的决心, 这样才能 帮助班级实现集体发展, 将班级构建为一个文明模范的班集 体。其次, 在工作上要有恒心。技工院校生源的质量比较低, 
班主任需要在工作中将阻力、压力转换为动力, 有效的进行 班级管理, 没有坚持下去的恒心是不可行的。一些教师在刚 开始当班主任的时候, 总会怀揣满腔热血, 全身心的投入在 班级工作中, 但是随着时间的推移, 班级琐事增多, 班主任就 会逐渐丧失管理班级的信心 ${ }^{[5]}$ 。如果遇到问题就打退堂鼓, 不仅意味着班级管理工作效率难以得到提升, 还可能对学生 的学习和发展产生影响。工作中三分钟热度很难实现对工作 质量的提升, 只有不断坚持, 脚踏实地的开展工作, 才能有效 管理班级, 实现班级管理工作质量和效率的全面提升。所以 在班主任工作中, 教师要始终保持恒心, 引导和帮助学生构 建良好的世界观、人生观, 只有这样才能帮助学生更好的发 展。最后, 教师还应该具备较强的责任心, 对于班级管理中出 现的问题要具备担当意识, 实现以身作则, 对学生起到榜样 作用, 只有用责任意识引导学生, 才能让学生对班主任更为 尊重, 推进班级管理工作的顺利开展。

\section{5 加强班风、学风建设工作}

第一, 加强对班风建设工作的有效开展。只有良好的班 风, 才能为学生带来更多的正能量, 一旦学生上进心得到提 升, 就会使班级整体形成更为健康和积极的学习氛围, 因此 在班风建设过程中, 可以从以下环节着手: 组织一个强有力 的班级干部委员会, 充分发挥班级干部在班级中的带头模范 作用。班委是班主任实现班级管理的主要帮手, 也是班级管 理的重要力量。所以, 教师可以采用民主推荐或是竞选演讲 的方式, 在学生中挑选一些更有担当和威信力的学生担任班 级干部, 在前期班级管理工作中, 教师应该积极引导和培养 班级干部, 通过对班级干部能力的提升, 使其成为班主任的 重要帮手 ${ }^{[6]}$ 。此外, 还要用制度对班级行为进行引导和规范。 制度建设中, 班主任也要组织学生进行相关讨论, 形成适合 班级发展的规章制度, 在经过全班同学探讨后, 在今后班级
管理中坚定不移的进行贯彻和执行。

第二, 加强班级中的学风建设。在班级管理过程中, 学风 建设也是最为关键的环节。班主任需要在工作中加强对学生 出勤率的掌握, 要求学生严格遵守课堂要求和纪律, 避免出 现在课堂上玩手机、打瞌睡的情况。对于一些自控力较差的 学生, 教师也要在课下多与其进行交流, 让学生认识到自身 的问题, 帮助并引导学生对问题和错误进行改进。此外, 班主 任还可以让学生制定自己的职业规划, 使学生调整学习态度, 帮助学生营造良好的学习风气。

\section{4 结束语}

班主任是班级管理中的关键因素, 因此在班级管理工作 中, 班主任更需要站在多个角度上对问题进行分析探索, 对 每项管理环节进行关注, 只有这样才能管理好班集体, 使班 集体更加优秀。在新时期, 班主任需要对学生的实际特征进 行掌握, 保持良好的教学态度和管理理念, 为班级的发展和 学生进步提供更大的帮助和指导。

\section{[参考文献]}

[1]赵若琳.新时期技工院校班主任管理工作的创新[J]. 新教育时代电子杂志(教师版),2018,14(2):297,282.

[2]王脣英.新时期技工院校班主任管理工作的创新[J]. 职业,2016,29(24):60-60.

[3] 宋玲.对新时期技工院校班级管理工作的思考[J].新 校园(上旬刊),2015,37(10):160.

[4]张晓丽.启迪心灵,完善自我——技工院校班主任如 何开展心理辅导工作[J].人文之友,2018,14(5):77.

[5]郑志霄.浅谈技工院校班主任工作的新思路[J].劳动 保障世界,2017,61(11):44.

[6]张顺利.技工院校班主任工作浅谈[J].中国校外教育 (理论),2014,39(9):61. 